\title{
Parathyroid Carcinoma pT1 TNM Finding v8
}

National Cancer Institute

\section{Source}

National Cancer Institute. Parathyroid Carcinoma pT1 TNM Finding v8. NCI Thesaurus.

Code C141064.

Tumor localized to the parathyroid gland with extension limited to soft tissue. (from AJCC 8th Ed.) 